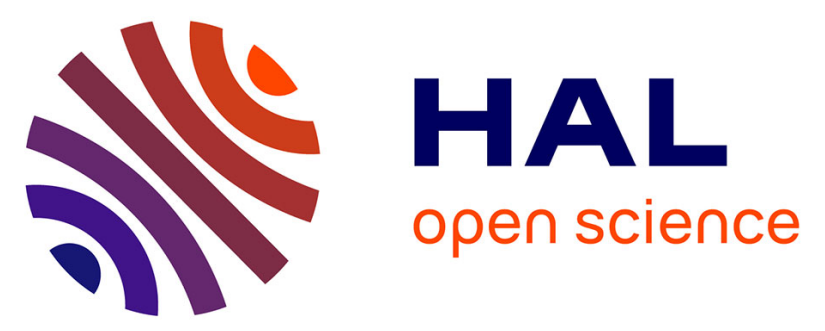

\title{
Increased hydrogen peroxide concentration in the exhaled breath condensate of stable COPD patients after nebulized -acetylcysteine
}

Jacek Rysz, Robert A. Stolarek, Rafal Luczynski, Agata Sarniak, Anna

Wlodarczyk, Marek Kasielski, Dariusz Nowak

\section{To cite this version:}

Jacek Rysz, Robert A. Stolarek, Rafal Luczynski, Agata Sarniak, Anna Wlodarczyk, et al.. Increased hydrogen peroxide concentration in the exhaled breath condensate of stable COPD patients after nebulized -acetylcysteine. Pulmonary Pharmacology \& Therapeutics, 2007, 20 (3), pp.281. 10.1016/j.pupt.2006.03.011 . hal-00499131

\section{HAL Id: hal-00499131 \\ https://hal.science/hal-00499131}

Submitted on 9 Jul 2010

HAL is a multi-disciplinary open access archive for the deposit and dissemination of scientific research documents, whether they are published or not. The documents may come from teaching and research institutions in France or abroad, or from public or private research centers.
L'archive ouverte pluridisciplinaire $\mathbf{H A L}$, est destinée au dépôt et à la diffusion de documents scientifiques de niveau recherche, publiés ou non, émanant des établissements d'enseignement et de recherche français ou étrangers, des laboratoires publics ou privés. 


\section{Author's Accepted Manuscript}

Increased hydrogen peroxide concentration in the exhaled breath condensate of stable COPD patients after nebulized $N$-acetylcysteine

Jacek Rysz, Robert A. Stolarek, Rafal Luczynski, Agata Sarniak, Anna Wlodarczyk, Marek Kasielski, Dariusz Nowak

PII: $\quad$ S1094-5539(06)00045-9

DOI: $\quad$ doi:10.1016/j.pupt.2006.03.011

Reference: $\quad$ YPUPT 677

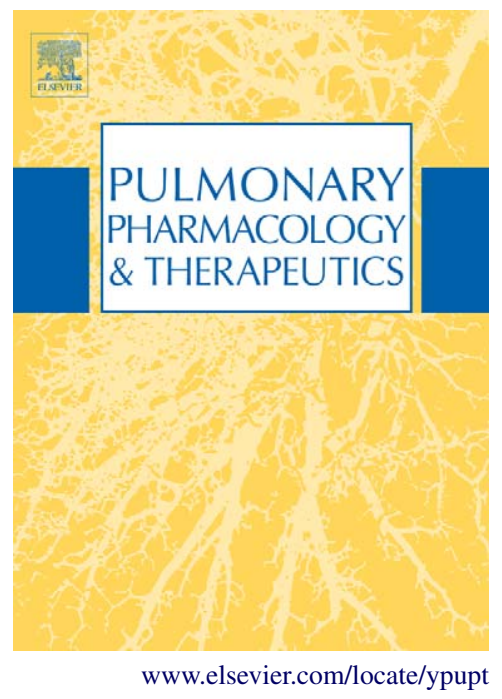

To appear in: $\quad$ Pulmonary Pharmacology \& Therapeutics

Received date: 2 January 2006

Revised date: 13 March 2006

Accepted date: 15 March 2006

Cite this article as: Jacek Rysz, Robert A. Stolarek, Rafal Luczynski, Agata Sarniak, Anna Wlodarczyk, Marek Kasielski and Dariusz Nowak, Increased hydrogen peroxide concentration in the exhaled breath condensate of stable COPD patients after nebulized $\mathrm{N}$-acetylcysteine, Pulmonary Pharmacology \& Therapeutics, doi:10.1016/j.pupt.2006.03.011

This is a PDF file of an unedited manuscript that has been accepted for publication. As a service to our customers we are providing this early version of the manuscript. The manuscript will undergo copyediting, typesetting, and review of the resulting galley proof before it is published in its final citable form. Please note that during the production process errors may be discovered which could affect the content, and all legal disclaimers that apply to the journal pertain. 
Increased hydrogen peroxide concentration in the exhaled breath condensate of stable COPD patients after nebulized $\mathrm{N}$-acetylcysteine

Jacek Rysz ${ }^{\#}$, Robert A. Stolarek, Rafal Luczynski, Agata Sarniak, Anna Wlodarczyk, Marek Kasielski*, Dariusz Nowak

Department of Clinical Physiology, Medical University of Lodz, Mazowiecka St. 6/8, 92-215 Lodz, Poland.

${ }^{\#} 2^{\text {nd }}$ Department of Family Medicine, Medical University of Lodz, Zeromskiego St. 113, 90-549

Lodz, Poland

*Center of Medical Education, Practical Training Center, Medical University of Lodz, Kopcinskiego St. 20, 90-154 Lodz, Poland.

Running head: exhaled $\mathrm{H}_{2} \mathrm{O}_{2}$ in COPD and nebulized $\mathrm{N}$-acetylcysteine

Address for correspondence:

Prof. Dariusz Nowak MD, PhD.

Department of Clinical Physiology

Medical University of Lodz

Mazowiecka St. 6/8

92-215 Lodz, Poland

Tel./Fax +48426782661

Email: dnowak@zdn.am.lodz.pl 


\section{Abstract}

Background: The oxidative burden in the airways is a hallmark of chronic obstructive pulmonary disease (COPD). Aims: This prospective, cross-over, placebo (PL) controlled study was designed to investigate the effect of $\mathrm{N}$-acetyl-L-cysteine (NAC) on hydrogen peroxide $\left(\mathrm{H}_{2} \mathrm{O}_{2}\right)$, nitrites/nitrates $\left(\mathrm{NO}_{2}^{-}+\mathrm{NO}_{3}^{-}\right)$and thiol $(\mathrm{RSH})$ concentrations in exhaled breath condensate (EBC) in stable COPD patients $\left(n=19\right.$, aged 52.6 \pm 15.6 years, 10 females, mean $\mathrm{FEV}_{1}$ 95.2 $\pm 23.8 \%$, $\mathrm{FEV}_{1} / \mathrm{FVC}$ 69.1 $\pm 11.4 \%$ ). Methods: $\mathrm{H}_{2} \mathrm{O}_{2}, \mathrm{NO}_{2}{ }^{-}+\mathrm{NO}_{3}{ }^{-}$and $\mathrm{RSH}$ concentrations in EBC were determined with homovanillic acid, NADPH-nitrite reductase assays and Ellman's reaction, respectively. Results: Thirty minutes after nebulization, $\mathrm{H}_{2} \mathrm{O}_{2}$ concentration increased if levels after NAC $(0.45 \pm 0.25 \mu \mathrm{M})$ and PL $(0.17 \pm 0.17 \mu \mathrm{M})$ were compared in COPD patients $(\mathrm{p}=0.002)$. This increased $\mathrm{H}_{2} \mathrm{O}_{2}$ level in $\mathrm{EBC}$ was no longer observed either after ninety minutes: $0.16 \pm 0.09 \mu \mathrm{M}(\mathrm{PL} 0.17 \pm 0.15 \mu \mathrm{M})$ or three hours: $0.12 \pm 0.07 \mu \mathrm{M}(\mathrm{PL} 0.21 \pm 0.23 \mu \mathrm{M})(\mathrm{p}=0.5$ and $\mathrm{p}=0.2$, respectively). The levels of $\mathrm{NO}_{2}{ }^{-}$and $\mathrm{NO}_{3}{ }^{-}$did not differ between NAC and PL. There was no significant difference in RSH levels between nebulized NAC and PL. After nebulized NAC, however, exhaled RSH increased from $1.42 \pm 1.69 \mu \mathrm{M}(0 \mathrm{~min})$ to $2.49 \pm 2.00 \mu \mathrm{M}(30 \mathrm{~min}$,) and $1.71 \pm 1.83 \mu \mathrm{M}(180 \mathrm{~min})(\mathrm{p}=0.009$ and $\mathrm{p}=0.03$, respectively, compared with $0 \mathrm{~min})$. Conclusions: These data demonstrate that nebulized NAC transiently increases exhaled $\mathrm{H}_{2} \mathrm{O}_{2}$ level, whereas it has no effect on other oxidative parameters.

Key words: N-acetylcysteine; hydrogen peroxide; nitrites; nitrates; chronic obstructive pulmonary disease; exhaled breath condensate. 


\begin{abstract}
Abbreviations: COPD chronic obstructive pulmonary disease, EBC exhaled breath condensate; GSNO S-nitrosogluthatione; $\mathrm{H}_{2} \mathrm{O}_{2}$ hydrogen peroxide; NAC N-acetyl-L-cysteine; $\mathrm{NO}_{2}{ }^{-}+\mathrm{NO}_{3}{ }^{-}$ nitrites and nitrates; PL placebo; PMNs polymorphonuclear leukocytes ; RNS reactive nitrogen species, ROS reactive oxygen species; RSH thiols; RSNO S-nitrosthiol.
\end{abstract}

\title{
Introduction
}

The oxidative burden in the airways is a hallmark of chronic obstructive pulmonary disease (COPD). Generation of reactive oxygen (ROS) and nitrogen species (RNS) coincides with increased lipid peroxidation, alveolar injury, increased endothelial permeability and extracellular matrix turnover, extensive mucus secretion and accumulation of activated macrophages and polymorphonuclear leukocytes [1]. Redox sensitive inflammatory transcription factors upregulated in the oxidative milieu may alter chromatin structure accounting for attenuation of inhaled steroid efficiency in COPD patients [2]. The increased nitrotyrosine and heme oxygenase and myeloperoxidase activities are specifically associated with COPD exacerbation [3]. The progressive deterioration of lung function and oxidative damage of lung parenchyma has an insidious time pattern and antioxidant approaches to COPD therapy have long now been considered as a likely beneficial option [1].

Nitric oxide (NO) is generated by sequestrated polymorphonuclear leukocytes and activated macrophages in the course of chronic inflammatory reaction in the lungs of COPD patients [4]. Its oxidation is terminated with nitrites and nitrates as stable end products. NO readily reacts with superoxide to from peroxynitrite $\left(\mathrm{ONOO}^{-}\right)$anion. It may initiate a set of reactions leading to extensive oxidative damage of histone deacetylase, antiproteases, surfactant, membrane lipids and the injury of alveolar epithelium [5]. Also, $\mathrm{ONOO}^{-}$formation leads to nitration and oxidation of protein sulfhydryl groups of the reduced cysteine and intracellular glutathione [6] along with 
the inhibition of antioxidant enzymes in a dose-dependent manner [7]. The levels of NO in exhaled air were demonstrated to correlate with accumulation of inflammatory cells and the functional indices of COPD exacerbation [8]. Exhaled breath condensate (EBC) is considered suitable for the assessment of airway inflammatory reactions [9] and nitrates levels in EBC were demonstrated to differ specifically in various diseases including asthma, COPD or community acquired pneumonia [10].

Several lines of evidence demonstrate the increased levels of $\mathrm{H}_{2} \mathrm{O}_{2}$ in the airways of COPD patients [1]. The increased $\mathrm{H}_{2} \mathrm{O}_{2}$ concentration in $\mathrm{EBC}$ was found in stable COPD patients [11, 12] and in the acute exacerbation [13]. The role of $\mathrm{H}_{2} \mathrm{O}_{2}$ may likely extend far beyond relatively stable ROS end product and oxidative injury parameter. $\mathrm{H}_{2} \mathrm{O}_{2}$ may act as a second messenger, sometimes in concert with $\mathrm{NO}$, and may regulate redox state of cysteine residues of signaling proteins including tyrosine kinase, PTEN and Ras [6]. The mean $\mathrm{EBC}_{2} \mathrm{O}_{2}$ level in COPD patients were 10 times higher than in healthy subjects, although it varied in a wide range $[12,13]$. The oral administration of NAC was demonstrated to decrease exhaled $\mathrm{H}_{2} \mathrm{O}_{2}$ in COPD patients $[11,14]$. Albeit inhaled NAC was shown to reduce even baseline levels of exhaled $\mathrm{H}_{2} \mathrm{O}_{2}$ in healthy subjects thirty minutes after its administration, the apparent increase of expired $\mathrm{H}_{2} \mathrm{O}_{2}$ was noted three hours later indicating either pro-oxidant effects or a rebound, oxidative response to antioxidant deposition in the airways [15].

NAC is a readily diffusible reductant aminothiol and a precursor of glutathione (GSH). The milimolar concentrations of intracellular GSH provide efficient scavenging of ROS and RNS. NAC scavenges hydroxyl radical and rapidly reacts with hypochlorous acid, inhibits oxidation of myeloperoxidase targets [16], exhibiting only a trace of affinity to $\mathrm{H}_{2} \mathrm{O}_{2}$ and none to superoxide anion [17]. NAC is able to upregulate gene expression at a transcriptional level facilitating cytoskeleton rebuilding and cell cycle arrest [18]. In the animal model, NAC appeared to hamper 
the progressive destruction of lung parenchyma and emphysema elicited by the specific inhibition of tyrosine kinase activity of VEGF receptors and attenuated the oxidative stress [19]. Albeit NAC in various route of administration indeed demonstrated appreciable benefits in COPD patients [20], the antioxidant effects of nebulized NAC have not been investigated so far in the setting of stable, mild COPD. Since intravenous GSH in healthy volunteers increased the level of cysteine in the expired air [21], it seems likely that inhaled NAC could increase airway GSH levels and improve antioxidant defense.

Thus, the prospective, double-blind, placebo-controlled study was designed to investigate the effects of nebulized NAC on hydrogen peroxide $\left(\mathrm{H}_{2} \mathrm{O}_{2}\right)$, nitrites and nitrates $\left(\mathrm{NO}_{2}{ }^{-} / \mathrm{NO}_{3}{ }^{-}\right)$and thiol (RSH) concentrations in exhaled breath condensate of stable COPD patients.

\section{Materials and Methods}

\section{Reagents and medications}

Homovanillic acid, NADPH-nitrate reductase (EC 1.6.6.2) from Aspergillus species, $\mathrm{NaNO}_{2}$, naphthylethylenediamide dihydrochloride, nicotinamide adenine dinucleotide phosphate reduced form (NADPH), peroxidase from horseradish type II (HRP; EC1.11.1.7), reduced glutathione (GSH) and sulphanilamide were obtained from Sigma Chemicals Co., St. Louis, MO. USA. Griess solutions: (A) $58.07 \mathrm{mM}$ sulphanilamide in $2 \mathrm{M}$ sulfuric acid and (B) $38.58 \mathrm{mM}$ naphthylethylenediamide dihydrochloride in deionized water were protected from light and stored at $4{ }^{\circ} \mathrm{C}$. Elman's reagent was prepared with 0,04 \% DTNB - 5,5 dithio-bis (2-nitrobenzoic acid) in $10 \%$ citrate solution. All remaining reagents were of analytical grade.

Fluimucil (300 mg of $\mathrm{N}$-acetylcysteine dissolved in $3 \mathrm{ml} \mathrm{H}_{2} \mathrm{O}$ injection grade, $2.7 \mathrm{mM}$ EDTA, $616.7 \mathrm{mM} \mathrm{NaOH}$ ) was commercially available from Zambon, Vicenza (Italy). Placebo-Fluimucil 
propellant alone $(3 \mathrm{ml}$ of sterile, deionized water with addition of $2.7 \mathrm{mM}$ EDTA, $75 \mathrm{mM} \mathrm{NaOH}$, $\mathrm{pH}$ adjusted to 6.6 with $\mathrm{HCl}$ ) was a sterile filtered, pyrogen free solution. NAC and placebo (PL) aerosol was generated with $3 \mathrm{ml}$ Fluimucil or PL sterile solution, respectively, placed inside automated (output $0.3 \mathrm{ml} / \mathrm{min}$ ) De Vilbiss 700 nebulizer (Sunrise Medical, Wollaston, Great Britain) wired up with pneumatic inhalator AP-50 De Vilbiss. Mean size of 50\% aerosol particles or mass median aerodynamic diameter did not exceed $4 \mu \mathrm{m}$.

The reagents were prepared freshly in deionized, pyrogen free water (resistance $>18 \mathrm{M} \Omega \mathrm{cm}$, HPLC Water Purification System USF ELGA, England) and kept on ice prior to use.

\section{Patients and study protocol}

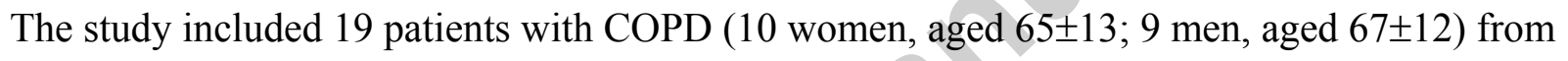
municipal hospital COPD patient registry (Table 1). Each enrolled patient had to meet the following inclusion criteria: (1) stage 0 , mild or moderate COPD diagnosis according to GOLD guidelines [22], (2) chest X-ray consistent with the diagnosis, (3) patients requiring only short acting $\beta$-2-agonist. The exclusion criteria included: (1) COPD exacerbation within prior three months; (2) patients receiving N-acetylcysteine or ambroxol within four months before the study; (3) bronchial asthma, cystic fibrosis, active tuberculosis, atopy, bronchiectasis, active malignancies; (4) creatinine clearance of below $30 \mathrm{ml} / \mathrm{min}$; (5) alanine and aspartate aminotransferase or alkaline phosphatase serum levels three times above the normal levels; (6) patients requiring non-steroid anti-inflammatory drugs, theophylline, long-acting $\beta$-2-agonists, inhaled steroids or oxygen therapy; (7) immunodeficiency or concomitant medication including immune suppressors, systemic inflammatory disease; (8) pregnant or breast-feeding females; (9) alcohol, illicit drug abuse. 
The study subjects were asked to attend the lab twice and were randomly chosen in double blind manner to receive assigned study medication package containing either nebulized Fluimucil (300 $\mathrm{mg}$ in $3 \mathrm{ml}$ ) or PL (3 ml) within two weeks' time. The dosage and dilution of nebulized Fluimucil preparation was according to common clinical practice and manufacturer's recommendations (Zambon Group, Italy) . The study protocol required lab staff to prepare solution for nebulization in a separate room and the delivery of the drug itself was conducted with the patient wearing a nose clip. EBC was collected before, 30, 90 and 180 min after either Fluimucil or PL inhalation. Lung function tests were performed according to the American Thoracic Society standards [23], initially during preselection phase, immediately before the first and just after the last EBC collection. The experiments started always between $8^{30}$ and $9^{00}$ and finished $13^{20}-13^{50}$. Each patient involved in the study gave informed consent and the study protocol was thoroughly reviewed and approved by the Institutional Review Board at Medical University of Lodz.

\section{Functional lung tests}

Master-Laboratory Screen (Jaeger Toennies, Wuerzburg, Germany) was used for lung functional tests including FVC (forced vital capacity), $\mathrm{FEV}_{1}$ (forced expiratory volume in the first second), $\mathrm{DLCO}_{\mathrm{c}}$ (single breath carbon monoxide diffusing capacity corrected for hemoglobin and alveolar volume), $\mathrm{RV}_{\mathrm{He}}$ (residual volume, helium dilution technique) according to the standard procedure $[23,24]$ and the results were expressed as percentage of predicted values $[23,25]$.

\section{Collection of exhaled breath condensate}

The EBC specimens for $\mathrm{H}_{2} \mathrm{O}_{2}$ assay were collected as previously described [15]. The amylase levels in EBC specimens were assayed as a control of salivary contamination with Vitros 250 assay (enzymatic test, lower detection limit 2 U/1, Johnson\&Johnson, Ortho Clinical Diagnostics, 
USA). The patient respiratory rate during EBC collection ranged from 14 to 19 breaths per minute. The procedure of EBC collection was 20 minutes and the mean volume of EBC was 5 ml. The EBC samples were processed in the assays for $\mathrm{H}_{2} \mathrm{O}_{2}$ and thiol content or were stored at $-80^{\circ} \mathrm{C}$ prior to nitrites/nitrates assays.

\section{Measurement of $\mathrm{H}_{2} \mathrm{O}_{2}$ in exhaled breath condensate}

The concentration of $\mathrm{H}_{2} \mathrm{O}_{2}$ in $\mathrm{EBC}$ was measured with previously described fluorometrical method [26,27]. Briefly, $600 \mu \mathrm{lEBC}, 300 \mu \mathrm{l} \mathrm{HRP}$ solution $(20 \mathrm{U} / \mathrm{ml})$ and $300 \mu \mathrm{l}$ of $200 \mu \mathrm{M}$ homovanillic acid solution were mixed and incubated for $60 \mathrm{~min}$ at $37^{\circ} \mathrm{C}$. Then, $0.1 \mathrm{M}$ glycine$\mathrm{NaOH}$ buffer ( $\mathrm{pH}$ 12.0) with $25 \mathrm{mM}$ EDTA was added and emission at $420 \mathrm{~nm}$ was determined with Perkin Elmer Luminescence Spectrometer LS-50B (Norwalk, CT, USA) at excitation at 312 $\mathrm{nm}$ in duplicate. The regression equation was: $\mathrm{y}[\mu \mathrm{M}]=0.068 \times\left(\mathrm{x}-\mathrm{x}_{0}\right)+0.152($ where $\mathrm{y}=$ micromoles of $\mathrm{H}_{2} \mathrm{O}_{2}$ per liter of exhaled breath condensate; $\mathrm{x}=$ intensity of emission at $420 \mathrm{~nm}$ expressed in arbitrary units; $\mathrm{x}_{\mathrm{o}}=$ intensity of emission given by reference sample with distilled water instead of EBC) [26]. For standard hydrogen peroxide solutions ranging from 0.1 to 0.5 $\mu \mathrm{M} \mathrm{H}_{2} \mathrm{O}_{2}$ intra-assay variability did not exceed $2 \%$. The detection limit of $\mathrm{H}_{2} \mathrm{O}_{2}$ assay was 0.1 $\mu \mathrm{M}$. The daily variability of $\mathrm{H}_{2} \mathrm{O}_{2}$ assay in EBC was less than $15 \%$. Among $152 \mathrm{H}_{2} \mathrm{O}_{2}$ assays in the study subjects, only four results were below the method sensitivity and they were assumed a half of detection limit for the purposes of data analysis.

\section{Nitrites and nitrates assay in exhaled breath condensate}

The modified method was used for the nitrites $\left(\mathrm{NO}_{2}{ }^{-}\right)$and nitrates $\left(\mathrm{NO}_{3}{ }^{-}\right)$assay with NADPHnitrite reductase [28]. EBC $(60 \mu \mathrm{l})$ was added in duplicate into 96 well plates with control wells 
containing the same volume of deionized water. Control samples received $60 \mu \mathrm{PBS}$ solution (pH 7.5). Then, $30 \mu \mathrm{l}$ of NADPH-nitrite reductase $(250 \mathrm{U} / \mathrm{ml})$, and $10 \mu \mathrm{l}$ of NADPH 0.625 $\mathrm{mg} / \mathrm{ml}$ solution were added into each well. The plates were incubated for 30 minutes at room temperature and protected from light, mixed with Griess solutions and absorbance was read at wavelength $562 \mathrm{~nm}$ with microplate reader EL 340 Bio-Tek Instruments (Winooski, VT, USA). Total $\mathrm{NO}_{2}{ }^{-}$was calculated with the values of absorbance directly from $\mathrm{NO}_{2}{ }^{-}$standard curve for the concentrations from 0.5 to $12.5 \mu \mathrm{M}$. The results were expressed as the sum of $\mathrm{NO}_{2}{ }^{-}$converted from $\mathrm{NO}_{3}{ }^{-}$plus $\mathrm{NO}_{2}{ }^{-}$originally detected. Concentration of $\mathrm{NO}_{3}{ }^{-}$was calculated by subtracting $\mathrm{NO}_{2}{ }^{-}$concentration before reduction from total $\mathrm{NO}_{2}{ }^{-}$concentration after the reduction. The daily variability nitrites/nitrates assay in EBC was below 7\% as assessed for up to 10 days.

\section{Assay of thiol compounds in exhaled breath condensate}

The equal volume $(500 \mu \mathrm{l})$ of EBC, $0.3 \mathrm{M} \mathrm{Na}_{2} \mathrm{PO}_{4}$ and Ellman's reagent were mixed on ice and the absorbance was read at $412 \mathrm{~nm}$ (Ultrospec III, Pharmacia LKB spectrophotometer). Control samples were supplemented with deionized water instead of EBC. Standard curve was prepared with serial dilutions of $200 \mu \mathrm{M}$ glutathione solution form 0.1 to $200 \mu \mathrm{M}$. The assays were ran in duplicate. The assay sensitivity was $0.25 \mu \mathrm{M}$ and the reproducibility $4.7 \%$ [15].

\section{Statistical analysis}

Data are expressed as arithmetic mean \pm standard deviation or median and range $[\mathrm{Me}, \mathrm{R}]$. The normality of distribution was assessed with either Shapiro-Wilk's or Kolmogorov-Smirnov test. The temporal pattern of variable changes and the differences between parameters after nebulized NAC and PL were analyzed either with Student $t$ or Wilcoxon matched-pair test. The differences 
between groups were analyzed with Mann-Whitney U test or Friedman ANOVA test. The Pearson correlation coefficient was used to assess the data interrelation. In all cases, a $p$ value $\leq$ 0.05 was considered significant.

\section{Results}

\section{Effect of nebulized N-acetylcysteine on lung function parameters in COPD patients}

The baseline characteristics of the study subjects is presented in Table 1. Lung functional parameters including $\mathrm{FVC}, \mathrm{FEV}_{1}, \mathrm{MEF} 25, \mathrm{PEF}$ and $\mathrm{FEV}_{1} / \mathrm{FVC}$ were not affected with either nebulized NAC or PL. Lung diffusing capacity $\mathrm{DLCO}_{\mathrm{c}}$ was $86.4 \pm 17.3 \%$ before and $84.9 \pm 15.5 \%$ 180 min after nebulized NAC and was similar in case of PL nebulization: $87.3 \pm 12.9$ and $86.8 \pm 13.4 \%$, respectively.

\section{Effect of $\mathrm{N}$-acetylcysteine on time course of $\mathrm{H}_{2} \mathrm{O}_{2}$ exhalation in COPD patients}

At baseline, the mean $\mathrm{H}_{2} \mathrm{O}_{2}$ concentration in COPD patients was $0.20 \pm 0.12 \mu \mathrm{M}$ before nebulized NAC and $0.34 \pm 0.76 \mu \mathrm{M}$ before nebulized PL, respectively $(\mathrm{p}>0.05)$. Thirty min after NAC inhalation, the mean $\mathrm{H}_{2} \mathrm{O}_{2}$ concentration reached $0.45 \pm 0.25 \mu \mathrm{M}$ (vs. PL $0.17 \pm 0.17 \mu \mathrm{M} ; \mathrm{p}<0.05$, if individual levels were compared, for details see Fig. 1). The $\mathrm{H}_{2} \mathrm{O}_{2}$ level in EBC after 90 min was $0.16 \pm 0.09 \mu \mathrm{M}$ (vs. PL $0.17 \pm 0.15 \mu \mathrm{M}$ ). After three hours, $\mathrm{H}_{2} \mathrm{O}_{2}$ level was $0.12 \pm 0.07 \mu \mathrm{M}$ and was similar if compared with the respective values after PL inhalation: $0.21 \pm 0.23 \mu \mathrm{M}$ (Table 2). There were no differences in the mean levels of exhaled $\mathrm{H}_{2} \mathrm{O}_{2}$ between NAC and PL at any of the study time points. However, exhaled $\mathrm{H}_{2} \mathrm{O}_{2}$ was increased if the exhaled $\mathrm{H}_{2} \mathrm{O}_{2}$ levels after nebulized PL were considered a background, confounding factor and were subtracted from exhaled $\mathrm{H}_{2} \mathrm{O}_{2}$ levels after nebulized NAC (Fig.1). The $\mathrm{H}_{2} \mathrm{O}_{2}$ levels in any given patient after PL 
were subtracted from respective $\mathrm{H}_{2} \mathrm{O}_{2}$ levels after NAC to determine if there were actual differences between PL and NAC (Fig.1). The levels of relative increase of exhaled $\mathrm{H}_{2} \mathrm{O}_{2}$ were significantly higher 30 min after nebulized NAC $(p=0.002)$. The time course of $\mathrm{H}_{2} \mathrm{O}_{2}$ exhalation for up to three hours after the nebulized NAC and PL in COPD patients is presented in Table 2.

Effect of $\mathrm{N}$-acetylcysteine on the time course of nitrites and nitrates exhalation in COPD patients

The EBC level of nitrites and nitrates $\left(\mathrm{NO}_{2}{ }^{-}\right.$and $\left.\mathrm{NO}_{3}{ }^{-}\right)$in COPD patients $(\mathrm{n}=19)$ before NAC nebulization was $0.51 \pm 0.49 \mu \mathrm{M}$ and $0.64 \pm 0.56 \mu \mathrm{M}$, respectively. The $\mathrm{NO}_{2}{ }^{-}$and $\mathrm{NO}_{3}{ }^{-}$ concentration was $0.61 \pm 0.45 \mu \mathrm{M}$ and $0.81 \pm 0.70 \mu \mathrm{M}$, respectively before PL inhalation ( $\mathrm{p}>0.05$ vs. before $\mathrm{NAC}$ ). $\mathrm{NO}_{2}{ }^{-}$and $\mathrm{NO}_{3}{ }^{-}$concentration did not differ between nebulized NAC and PL at any time point. Thirty min after inhaled $\mathrm{NAC}$ (or $\mathrm{PL}$ ), $\mathrm{NO}_{2}^{-}$and $\mathrm{NO}_{3}{ }^{-}$concentration reached $0.51 \pm 0.31 \mu \mathrm{M}(\mathrm{PL} 0.59 \pm 0.35 \mu \mathrm{M})$ and $0.96 \pm 0.75 \mu \mathrm{M}(\mathrm{PL} 1.11 \pm 1.68 \mu \mathrm{M})$, respectively and then $0.41 \pm 0.22 \mu \mathrm{M}(\mathrm{PL} 0.33 \pm 0.30 \mu \mathrm{M})(\mathrm{p}>0.05) 90$ min later. Eventually, $180 \mathrm{~min}$ after nebulized $\mathrm{NAC}$ (or PL), $\mathrm{NO}_{2}{ }^{-}$and $\mathrm{NO}_{3}{ }^{-}$concentration was $0.82 \pm 0.82 \mu \mathrm{M}(\mathrm{PL} 0.87 \pm 0.67 \mu \mathrm{M})$ and $0.70 \pm 0.50 \mu \mathrm{M}(\mathrm{PL} 0.58 \pm 0.36 \mu \mathrm{M})$, respectively, $(\mathrm{p}>0.05)$. The analysis of time course of exhaled nitrites and nitrates levels in COPD patients is presented in Fig. 2A and 2B.

\section{Effect of $\mathrm{N}$-acetylcysteine on the time course of thiol exhalation in COPD patients}

With regard to the changes at the consecutive time points, after nebulized NAC the EBC concentration of thiols increased from $1.42 \pm 1.69 \mu \mathrm{M}(0 \mathrm{~min})$ to $2.49 \pm 2.00 \mu \mathrm{M}(30 \mathrm{~min}, \mathrm{p}=0.009$ if compared with $0 \mathrm{~min})$ and $1.71 \pm 1.83 \mu \mathrm{M}(180 \mathrm{~min}, \mathrm{p}=0.03$ if compared with $0 \mathrm{~min})$. After nebulized PL, the EBC thiol concentration varied from $1.75 \pm 1.56 \mu \mathrm{M}(0 \mathrm{~min})$ to $1.73 \pm 1.82 \mu \mathrm{M}$ 
(30 min) and $2.13 \pm 1.96 \mu \mathrm{M}(180 \mathrm{~min})(\mathrm{p}>0.05$, in each time point) (Table 3). The differences in RSH levels between nebulized NAC and PL were not significant. For detailed comparisons, see Figure 3. The thiols content variability evaluated in the same subjects before either PL or NAC inhalation was $16 \%$. In statistical terms, the differences between the same patients before PL and NAC nebulization were not significant.

\section{Correlation between exhaled breath condensate parameters}

Both 30 min. and $180 \mathrm{~min}$. after nebulized NAC, there was significant, positive correlation between the EBC concentration of nitrates and RSH: $r=0.67$ and $r=0.80 ;(p=0.02$ and $p=0.003)$, respectively. Further, the EBC concentrations of $\mathrm{RSH}$ and $\mathrm{H}_{2} \mathrm{O}_{2}$ were significantly interrelated $(\mathrm{r}=0.78 ; \mathrm{p}=0.003) 180 \mathrm{~min}$ after NAC nebulization. None of these relationships were noted after nebulized PL in the same subjects.

\section{Discussion}

The range of $\mathrm{H}_{2} \mathrm{O}_{2}$ concentrations detected in our study patients is consistent with their clinical characteristics of mild or stage 0 , stable COPD. The stable COPD subjects in our study presented with exhaled $\mathrm{H}_{2} \mathrm{O}_{2}$ levels below those reported in moderate and severe COPD stage [11,14] or COPD exacerbation [13]. EBC levels of $\mathrm{H}_{2} \mathrm{O}_{2}$ in patients with more advanced, moderate COPD were previously shown to be 10 times higher than in healthy controls [12]. They are approximately twice higher than $\mathrm{H}_{2} \mathrm{O}_{2}$ levels in COPD patient included into the present study and the current $\mathrm{COPD} \mathrm{H}_{2} \mathrm{O}_{2}$ levels are still 4 times higher than those reported in healthy subjects [12]. Oral $\mathrm{N}$-acetylcysteine was demonstrated to decrease exhaled $\mathrm{H}_{2} \mathrm{O}_{2}$ in stable COPD patients [11,14]. Previously, the decreased exhaled $\mathrm{H}_{2} \mathrm{O}_{2}$ levels were found 30 min after nebulized NAC 
in parallel with the significant levels of $\mathrm{H}_{2} \mathrm{O}_{2}$ generated in NAC solution used for nebulization under in vitro conditions [15]. Inhaled NAC entirely inhibited $\mathrm{H}_{2} \mathrm{O}_{2}$ exhalation half an hour and increased $\mathrm{H}_{2} \mathrm{O}_{2}$ approximately twice three hours after its nebulization in healthy, non-smoking subjects [15]. Conversely, in the current patients with COPD, NAC increased exhaled $\mathrm{H}_{2} \mathrm{O}_{2}$ half an hour later above the reference levels returning to baseline at later time points. If the increased $\mathrm{H}_{2} \mathrm{O}_{2}$ level in the current study were due to the auto-oxidation in NAC solution, the increase could likely be noticeable not only $30 \mathrm{~min}$. after nebulized NAC, but also on further time points, as in our former study [15]. The contribution of auto-oxidation in NAC solution would be most probably only minor after half an hour of its deposition in the airways. Therefore, it seems more credible that the temporary and short-lived $\mathrm{H}_{2} \mathrm{O}_{2}$ increase is related with redox interactions in the airways of COPD patients.

The clinical attempts to evaluate the redox effects of drugs commonly encounter similar obstacles related with the biased understanding of the redox reactions and their relativity with respect to physical and chemical parameters. Also, it may be over simplistic to assume that NAC may have pro-oxidant side effects [20]. The redox potential of cysteine/cystine couple is reportedly high enough to oxidize corresponding glutathione GSH/GSSG couple and act not as an oxidant but as a critical intracellular redox control of protein activity [29]. NAC may increase $\mathrm{H}_{2} \mathrm{O}_{2}$ levels mediating the increase of intracellular NO and provide an excess of thiol groups that redirect NO away from cellular targets and enhance ROS generation [30,31]. Additionally, ROS may be generated in the aerobic lung environment in the reactions involving native or thiol bound NO and glutathione or cysteine [32]. The ionized part of nebulized NAC would immediately react with $\mathrm{H}_{2} \mathrm{O}_{2}$ and decrease $\mathrm{H}_{2} \mathrm{O}_{2}$ levels. That could contribute to the decrease of $\mathrm{H}_{2} \mathrm{O}_{2}$ in healthy subjects half an hour after inhaled NAC. However, if nebulized NAC were to from S-nitrosothiols in the reaction between NO and NAC, that could lead to the increased 
exhaled $\mathrm{H}_{2} \mathrm{O}_{2}$ due to initiation of the net of redox reaction favoring the formation of $\mathrm{H}_{2} \mathrm{O}_{2}$ from superoxide anion. Notably, the halftime of S-nitrosogluthatione (GSNO) of approximately 30 min. would be ideal to support this interpretation, as at this time increased $\mathrm{H}_{2} \mathrm{O}_{2}$ was found in our patients. Further, if this hypothetical redox chemistry were correct, half an hour after nebulized NAC we would in fact observe thiol-induced washout of excessive $\mathrm{H}_{2} \mathrm{O}_{2}$. In order to verify this, additional in vitro experiments on the interactions between NAC and GSNO would have to be designed. It would have been crucial for their validation to demonstrate that NAC is able to trigger redox reactions with nitrosothiols in the presence of oxygen and generate ROS.

Fortunately, these experiments have already been conducted with cysteine. Hydroxyl radical $\bullet \mathrm{OH}$ and thiyl radicals $\bullet$ RS are generated by cysteine gradually decomposing S-nitrosogluthatione [32] and are capable of forming $\mathrm{H}_{2} \mathrm{O}_{2}$.

NAC may initiate and interfere with other specific reactions in the airways of COPD patients. Thiol compounds ( $\mathrm{RSH})$, unlike ionized thiolates $\left(\mathrm{RS}^{-}\right)$, do not react with $\mathrm{H}_{2} \mathrm{O}_{2}[6]$ and it is unlikely non-ionized NAC would directly alter $\mathrm{H}_{2} \mathrm{O}_{2}$ levels. Also, reaction of superoxide anion $\cdot \mathrm{O}_{2}^{-}$with $\mathrm{RSH}$ is probable in the airways but quite unlikely significant at the intracellular level due to rapid dismutation of $\mathrm{O}_{2}^{-}[6]$. S-nitrosoglutathione and $\mathrm{NAC}$ derivative not only release NO but effectively increase the extend and selectivity of NO action. RSNO stabilizes NO reactivity and increases its half-life redirecting its target actions into more selective thioregulatory functions upon proteins [33]. The reaction between RNS and NAC initially involved the intermediates on the redox path to nitrates and nitrites. NAC may react with either nitrogen dioxide radical $\left(\cdot \mathrm{NO}_{2}\right)$ as well as directly with nitric oxide or nitrogen trioxide $\left(\mathrm{N}_{2} \mathrm{O}_{3}\right)$ to from S-nitrosthiol [6]. Further, NAC may inhibit the heme oxygenase mediated oxidation and increase iron levels in COPD. The lung parenchyma overload with iron in smoking COPD patients may accelerate not only Fenton's reaction but also nitrosothiol formation in the reaction 
introsonim ion intermediate. Ionized thiol adduct with iron are characterized with the increased reactivity compared with native thiols [6]. Proximity of a redox metal to a target thiol may be an important factor in thiol nitrosylation. Finally, the forms of ionized thiolates (RS ${ }^{-}$) and thiyl radicals $(\cdot \mathrm{RS})$, including not only NAC but also GSH pools, in aerobic conditions from superoxide anion, eventually decomposing to hydrogen peroxide detected in our COPD patients.

The existing data on interrelation between lung functional and oxidative parameters in subjects with COPD provide evidence on the reverse relation between $\mathrm{FEV}_{1}$ values and nitrotyrosine formation [4]. In the experimental setting with nebulized thiols, GSNO increased expired NO for up to 30 minutes in cystic fibrosis patients [34]. Reduced and oxidized glutathione and nitrosothiols were increased approximately twice in COPD patients but exhaled NO did not correlate with nitrosothiols [35]. NAC may function as an NO antagonist by providing an excess of thiol groups that redirect NO [31]. Nitrates and nitrites levels in EBC were related with increased exhaled levels of $\mathrm{H}_{2} \mathrm{O}_{2}[36]$ and their increased levels in asthmatic patients were similar as those reported hereby [28]. Nitrates were elevated in smokers, whereas were not reportedly increased in COPD patients [10]. Also, nebulization alone may accelerate droplet formation at epithelial lining fluid. Due to both decreased mucus viscosity and increased mucociliary clearance, more droplets from lower airways epithelial lining are blown away and moved upwards.

The existing clinical data on inhaled NAC confirm insignificant effects on forced expiratory parameters even if NAC did appear to improve exercise-induced desaturation in pulmonary fibrosis [37]. NAC recently turned out ineffective in reducing annual number of exacerbation and did not prevent from deteriorating $\mathrm{FEV}_{1}$ in COPD patients in a randomized, placebo-controlled, three-year study [38]. 
Apparently, the clinical significance of NAC nebulization in this group of patients merely exceeds placebo effects. Although the relevance of these observations remains yet to be established, this study provides some novel evidence on pro-oxidant effects of nebulized NAC. Albeit these effects were short-lived and moderate in COPD patients, they may be specifically associated with increased thiol oxidative turnover further accelerated by NAC deposition in airways.

\section{Acknowledgements}

This study was supported by Ministry of Education and Science grant no. PBZ-KBN094/P06/2003/01 and Medical University of Lodz institutional grant no. 503-0079-1. 


\section{References}

1. Rahman I. Oxidative stress in pathogenesis of chronic obstructive pulmonary disease: cellular and molecular mechanisms. Cell Biochem Biophys 2005; 43: 167-88.

2. Adcock IM, Cosio B, Tsaprouni L, Barnes PJ, Ito K. Redox regulation of histone deacetylases and glucocorticoid-mediated inhibition of the inflammatory response. Antioxid Redox Signal 2005; 7:144-52.

3. Tsoumakidou M, Tzanakis N, Chrysofakis G, Siafakas NM. Nitrosative stress, heme oxygenase-1 expression and airway inflammation during severe exacerbation of COPD. Chest 2005; 127: 1911-8.

4. Ichinose M, Sugiura H, Yamagata S, Koarai A, Shirato K. Increase in reactive nitrogen species production in chronic obstructive pulmonary disease airways. Am J Respir Crit Care Med 2000; 162(2 Pt 1): 701-6.

5. Barnes PJ, Ito K, Adcock IM. Corticosteroid resistance in chronic obstructive pulmonary disease: inactivation of histone deacetylase. Lancet 2004; 28; 363: 731-3.

6. Forman HJ, Fukuto JM, Torres M. Redox signaling: thiol chemistry defines which reactive oxygen and nitrogen species can act as second messengers. Am J Physiol Cell Physiol 2004; 287:C246-56.

7. Lawler JM, Song W. Specificity of antioxidant enzyme inhibition in skeletal muscle to reactive nitrogen species donors. Biochem Biophys Res Commun 2002; 294:1093-100.

8. Rutgers SR, van der Mark TW, Coers W, Moshage H, Timens W, Kauffman HF, Koeter GH, Postma DS. Markers of nitric oxide metabolism in sputum and exhaled air are not increased in chronic obstructive pulmonary disease. Thorax 1999; 54: 576-80.

9. Mutlu GM, Garey KW, Robbins RA, et al. Collection and analysis of exhaled breath condensate in humans. Am J Respir Crit Care Med 2001; 164: 731-737. 
10. Corradi M, Pesci A, Casana R, Alinovi R, Goldoni M, Vettori MV, Cuomo A. Nitrate in exhaled breath condensate of patients with different airway diseases. Nitric Oxide 2003; 8: $26-30$.

11. De Benedetto F, Aceto A, Dragani B, Spacone A, Formisano S, Pela R, Donner CF, Sanguinetti CM. Long-term oral N-acetylcysteine reduces exhaled hydrogen peroxide in stable COPD. Pulm Pharmacol Ther 2005; 18:41-7.

12. Nowak D, Kasielski M, Antczak A, Pietras T, Bialasiewicz P. Increased content of thiobarbituric acid-reactive substances and hydrogen peroxide in the expired breath condensate of patients with stable chronic obstructive pulmonary disease: no significant effect of cigarette smoking. Respir Med 1999; 93:389-96.

13. Dekhuijzen PN, Aben KK, Dekker I, Aarts LP, Wielders PL, van Herwaarden CL, Bast A Increased exhalation of hydrogen peroxide in patients with stable and unstable chronic obstructive pulmonary disease. Am J Respir Crit Care Med 1996; 154: 813-816.

14. Kasielski M, Nowak D. Long-term administration of N-acetylcysteine decreases hydrogen peroxide exhalation in subjects with chronic obstructive pulmonary disease. Respir Med 2001; 95:448-56.

15. Szkudlarek U, Zdziechowski A, Witkowski K, Kasielski M, Luczynska M, Luczynski R, Sarniak A, Nowak D. Effect of inhaled N-acetylcysteine on hydrogen peroxide exhalation in healthy subjects. Pulmon Pharm Theraup 2004; 17: 155-162.

16. Van Antwerpen P, Boudjeltia KZ, Babar S, Legssyer I, Moreau P, Moguilevsky N, Vanhaeverbeek M, Ducobu J, Neve J. Thiol-containing molecules interact with the myeloperoxidase/H2O2/chloride system to inhibit LDL oxidation. Biochem Biophys Res Commun 2005; 337: 82-8. 
17. Aruoma OI, Halliwell B, Hoey BM, Butler J. The antioxidant action of N-acetylcysteine: its reaction with hydrogen peroxide, hydroxyl radical, superoxide, and hypochlorous acid. Free Radic Biol Med 1989; 6: 593-7.

18. Edlundh-Rose E, Kupershmidt I, Gustafsson AC, Parasassi T, Serafino A, BracciLaudiero L, Greco G, Krasnowska EK, Romano MC, Lundeberg T, Nilsson P, Lundeberg J. Gene expression analysis of human epidermal keratinocytes after N-acetyl L-cysteine treatment demonstrates cell cycle arrest and increased differentiation. Pathobiology 2005; 72:203-12.

19. Voelkel N, Taraseviciene-Stewart L. Emphysema: an autoimmune vascular disease? Proc Am Thorac Soc 2005; 2: 23-5.

20. Kinnula VL. Focus on antioxidant enzymes and antioxidant strategies in smoking related airway diseases. Thorax 2005; 60: 693-700.

21. Fukagawa NK, Ajami AM, Young VR. Plasma methionine and cysteine kinetics in response to an intravenous glutathione infusion in adult humans. Am J Physiol 1996; 270:E209-14.

22. GOLD Workshop Report. Global strategy for the diagnosis, management, and prevention of chronic obstructive pulmonary disease. Bethesda, Md.: NHLBI, 2005.

23. American Thoracic Society. Standardization of spirometry: 1994 update. Am J Respir Crit Care Med 1995; 152: 1107-1136.

24. Single-breath carbon monoxide diffusing capacity (transfer factor). Recommendations for a standard technique - 1995 Update. Am J Respir Crit Care Med 1995: 152: 2185-98.

25. Carpo RO, Morris AH. Standarized single breath normal values for carbon monoxide diffusing capacity. Am Rev Respir Dis 1981; 123:185-9. 
26. Nowak D, Kalucka S, Bialasiewicz P, Krol M. Exhalation of $\mathrm{H}_{2} \mathrm{O}_{2}$ and thiobarbituric acid reactive substances (TBARs) by healthy subjects. Free Rad Biol Med 2001; 30: 178-86.

27. Ruch W, Cooper PH, Baggiolonii M. Assay of $\mathrm{H}_{2} \mathrm{O}_{2}$ production by marcophages and neutrophils with homovanillic acid and horseradish peroxidase. J Immunol Meth 1983; 63: $347-57$.

28. Dziedzic B, Mazanowska-Gajdowicz J, Walczewska A, Sarniak A, Nowak D. Comparison of cadmium and enzyme-catalyzed nitrate reduction for determination of NO2-/NO3- in breath condensate. Clin Chim Acta 2003; 335: 65-74.

29. Jones DP, Go YM, Anderson CL, Ziegler TR, Kinkade JM, Kirlin WG. Cysteine/cystine couple is a newly recognized node in the circuitry for biologic redox signaling and control. FASEB J 2004; 18:1246-8.

30. Borutaite V, Brown GC. Nitric oxide induces apoptosis via hydrogen peroxide, but necrosis via energy and thiol depletion. Free Radic Biol Med 2003; 35:1457-68.

31. Motterlini R, Foresti R, Bassi R, Calabrese V, Clark JE, Green CJ. Endothelial Heme Oxygenase-1 Induction By Hypoxia Modulation By Inducible Nitric-Oxide Synthase And S-Nitrosothiols. J Biol Chem 2000, 275: 13613-13620.

32. Kikugawa K, Oikawa N, Miyazawa A, Shindo K, Kato T. Interaction of nitric oxide with glutathione or cysteine generates reactive oxygen species causing DNA single strand breaks. Biol Pharm Bull 2005; 28: 998-1003.

33. Stamler JS. S-nitrosothiols and the bioregulatory actions of nitrogen oxides through reactions with thiol groups. Curr Top Microbiol Immunol 1995; 196:19-36.

34. Snyder AH, McPherson ME, Hunt JF, Johnson M, Stamler JS, Gaston B. Acute effects of aerosolized S-nitrosoglutathione in cystic fibrosis. Am J Respir Crit Care Med. 2002; 165: $922-6$. 
35. Beeh KM, Beier J, Koppenhoefer N, Buhl R.Increased glutathione disulfide and nitrosothiols in sputum supernatant of patients with stable COPD. Chest 2004; 126: 111622.

36. Ganas K, Loukides S, Papatheodorou G, Panagou P, Kalogeropoulos N. Total nitrites/nitrate in expired breath condensate of patients with asthma. Respir Med. 2001; $95: 649-54$.

37. Tomioka H, Kuwata Y, Imanaka K, Hashimoto K, Ohnishi H, Tada K, Sakamoto H, Iwasaki H. A pilot study of aerosolized N-acetylcysteine for idiopathic pulmonary fibrosis. Respirology 2005; 10:449-55.

38. Decramer M, Rutten-van Molken M, Dekhuijzen PN, Troosters T, van Herwaarden C, Pellegrino R, van Schayck CP, Olivieri D, Del Donno M, De Backer W, Lankhorst I, Ardia A. Effects of N-acetylcysteine on outcomes in chronic obstructive pulmonary disease (Bronchitis Randomized on NAC Cost-Utility Study, BRONCUS): a randomised placebo-controlled trial. Lancet 2005; 365:1552-60. 
Table 1

Characteristics of study subjects

\begin{tabular}{|c|c|c|c|c|}
\hline \multicolumn{5}{|c|}{ COPD patients } \\
\hline Number & \multicolumn{4}{|c|}{19} \\
\hline gender $\mathrm{M} / \mathrm{F}$ & \multicolumn{4}{|c|}{$9 / 10$} \\
\hline age (yrs) & \multicolumn{4}{|c|}{$52.6 \pm 15.6$} \\
\hline Current smokers (pack years) & \multicolumn{4}{|c|}{$14(20 \pm 14)$} \\
\hline BMI $\left[\mathrm{kg} / \mathrm{m}^{2}\right]$ & \multicolumn{4}{|c|}{$26.9 \pm 3.7$} \\
\hline HGB [g/dl] & \multicolumn{4}{|c|}{$13.9 \pm 1.8$} \\
\hline $\mathrm{WBC}\left[\times 10^{3} / \mu \mathrm{l}\right]$ & \multicolumn{4}{|c|}{$7.22 \pm 2.47$} \\
\hline \multirow{2}{*}{ Lung functional parameters } & \multicolumn{2}{|c|}{ Before nebulization } & \multicolumn{2}{|c|}{ After nebulization } \\
\hline & $N A C$ & $P L$ & $N A C$ & $P L$ \\
\hline $\mathrm{FEV}_{1} \%$ & $95.2 \pm 23.8$ & $97.4 \pm 22.9$ & $95.3 \pm 21.8$ & $97.7 \pm 22.7$ \\
\hline FVC \% & $112.7 \pm 15.6$ & $113.3 \pm 13.3$ & $111.1 \pm 12.0$ & $114.7 \pm 13$ \\
\hline $\mathrm{FEV}_{1} / \mathrm{FVC} \%$ & $69.1 \pm 11.4$ & $70.3 \pm 11.4$ & $70.4 \pm 12.1$ & $69.9 \pm 12.6$ \\
\hline PEF \% & $63.2 \pm 24.3$ & $75.2 \pm 22.8$ & $74.8 \pm 22.9$ & $71.9 \pm 23.5$ \\
\hline MEF $25 \%$ & $65.7 \pm 24.9$ & $68.2 \pm 26.7$ & $70.7 \pm 26.7$ & $69.0 \pm 26.5$ \\
\hline $\mathrm{RV}_{\mathrm{He}} \%$ & $112.0 \pm 43.9$ & $124.1 \pm 31.6$ & $127.3 \pm 30.1$ & $120.9 \pm 35.0$ \\
\hline $\mathrm{DLCO}_{\mathrm{c}} \%$ & $86.4 \pm 17.3$ & $87.3 \pm 12.9$ & $84.9 \pm 15.4$ & $86.8 \pm 13.4$ \\
\hline
\end{tabular}

The study included 9 patients at stage 0 COPD, 7 with mild and 3 with moderate COPD. Lung functional parameters are expressed as percentage of the predicted value; FVC- forced vital capacity, $\mathrm{FEV}_{1}$ - forced expiratory volume in the first second, $\mathrm{DLCO}_{\mathrm{c}}-\operatorname{single}$ breath carbon monoxide diffusing capacity corrected for hemoglobin and alveolar volume, $\mathrm{RV}_{\mathrm{He}}$-residual volume, BMI- body mass index, NAC-N-acetyl-L-cysteine, PL-placebo. 
Table 2. Hydrogen peroxide in exhaled breath condensate of COPD patients after inhalation of $\mathrm{N}$-acetylcysteine and placebo

\begin{tabular}{|c|c|c|c|c|}
\hline \multirow{2}{*}{ Inhaled solution (3 ml) } & \multicolumn{4}{|c|}{$\mathrm{H}_{2} \mathbf{O}_{2}$ levels $(\mu \mathrm{M})$ in EBC } \\
\cline { 2 - 5 } & Before & 30 min after & $\mathbf{9 0}$ min after & 3h after \\
\hline \multirow{2}{*}{ NAC (300 mg) } & $0.20 \pm 0.29$ & $0.45 \pm 0.25^{\#}$ & $0.16 \pm 0.09$ & $0.12 \pm 0.07$ \\
& {$[0.13 ; 1.33]$} & {$[0.46 ; 0.88]$} & {$[0.15 ; 0.41]$} & {$[0.11 ; 0.34]$} \\
\hline \multirow{2}{*}{ Placebo } & $0.17 \pm 0.16$ & $0.17 \pm 0.17$ & $0.17 \pm 0.15$ & $0.21 \pm 0.23$ \\
& {$[0.13 ; 0.7]$} & {$[0.11 ; 0.73]$} & {$[0.13 ; 0.58]$} & {$[0.14 ; 0.97]$} \\
\hline
\end{tabular}

${ }^{\#} \mathrm{p}=0.087 \mathrm{vs}$. before (border of significance), for detailed comparison with placebo effects see Figure 1. Median $(\mathrm{Me})$ and range $(\mathrm{R})$ are provided in brackets [Me; $\mathrm{R}]$ 
Table 3. Effect of $\mathbf{N}$-acetylcysteine and placebo on the time course of thiol exhalation in COPD patients

\begin{tabular}{|c|c|c|c|}
\hline \multirow{2}{*}{ Inhaled solution $(3 \mathrm{ml})$} & \multicolumn{3}{|c|}{ EBC thiol levels $(\mu \mathrm{M})$} \\
\cline { 2 - 4 } & Before & 30 min after & 3 h after \\
\hline \multirow{2}{*}{ NAC } & $1.42 \pm 1.69$ & $2.49 \pm 2.00^{*}$ & $1.71 \pm 1.83^{\#}$ \\
& {$[0.73 ; 4.58]$} & {$[2.27 ; 5.66]$} & {$[0.95 ; 5.24]$} \\
\hline \multirow{2}{*}{ Placebo } & $1.75 \pm 1.56$ & $1.73 \pm 1.82$ & $2.13 \pm 1.96$ \\
& {$[1.28 ; 5.02]$} & {$[1.06 ; 5.89]$} & {$[1.94 ; 6.77]$} \\
\hline
\end{tabular}

There was no significant difference in thiol levels between nebulized N-acetylcysteine (NAC) and placebo. If the consecutive time points were compared, EBC concentration of thiols increased after nebulized NAC after $30 \mathrm{~min}$ ( $\mathrm{p}=0.009$ if compared with $0 \mathrm{~min}$ ) and $180 \mathrm{~min}$ ( $\mathrm{p}=0.03$ if compared with $0 \mathrm{~min}$ ). Mean values \pm standard deviation are presented. Median $(\mathrm{Me})$ and range $(\mathrm{R})$ are provided in brackets $[\mathrm{Me} ; \mathrm{R}]{ }^{*} p=0.009$ vs. baseline (before), ${ }^{\#} p=0.03$ vs. baseline; for detailed comparison with placebo see Figure 3. 
Table 4. Effect of $\mathbf{N}$-acetylcysteine and placebo on the time course of nitrites and nitrates exhalation in COPD patients

\begin{tabular}{|c|c|c|c|c|}
\hline \multirow{2}{*}{ Inhaled solution (3 ml) } & \multicolumn{4}{|c|}{ EBC nitrates levels $(\mu \mathrm{M})$} \\
\cline { 2 - 5 } & Before & $\mathbf{3 0}$ min after & $\mathbf{9 0}$ min after & $\mathbf{1 8 0}$ min after \\
\hline \multirow{2}{*}{ NAC (300 mg) } & $0.64 \pm 0.56$ & $0.96 \pm 0.75$ & $0.85 \pm 0.83$ & $0.82 \pm 0.82$ \\
& {$[0.41 ; 2.16]$} & {$[0.68 ; 2.74]$} & {$[0.63 ; 3.02]$} & {$[0.84 ; 3.62]$} \\
\hline \multirow{2}{*}{ Placebo } & $0.81 \pm 0.70$ & $1.11 \pm 1.68$ & $0.82 \pm 0.63$ & $0.87 \pm 0.67$ \\
& {$[0.81 ; 2.30]$} & {$[0.68 ; 7.46]$} & {$[0.79 ; 2.04]$} & {$[0.90 ; 2.14]$} \\
\hline \multirow{2}{*}{ Inhaled solution $(3 \mathrm{ml})$} & & EBC nitrites levels $(\mu \mathrm{M})$ \\
\cline { 2 - 5 } & Before & $\mathbf{3 0}$ min after & $\mathbf{9 0}$ min after & $\mathbf{1 8 0}$ min after \\
\hline \multirow{2}{*}{ NAC (300 mg) } & $0.51 \pm 0.49$ & $0.51 \pm 0.31$ & $0.41 \pm 0.22$ & $0.70 \pm 0.50$ \\
& {$[0.34 ; 1.65]$} & {$[0.50 ; 1.15]$} & {$[0.39 ; 0.60]$} & {$[0.61 ; 2.03]$} \\
\hline \multirow{2}{*}{ Placebo } & $0.61 \pm 0.45$ & $0.59 \pm 0.35$ & $0.33 \pm 0.30$ & $0.58 \pm 0.36$ \\
& {$[0.45 ; 1.81]$} & {$[0.56 ; 1.32]$} & {$[0.33 ; 0.99]$} & {$[0.56 ; 1.43]$} \\
\hline
\end{tabular}

Mean values \pm standard deviation are presented. Median $(\mathrm{Me})$ and range $(\mathrm{R})$ are provided in brackets $[\mathrm{Me} ; \mathrm{R}]$. There were no significant changes of nitrite and nitrate levels at any time point. There was no significant differences between these parameters at the study time points. 
Figure 1. Relative EBC $\mathrm{H}_{2} \mathrm{O}_{2}$ concentration in COPD patients after nebulized Nacetylcysteine

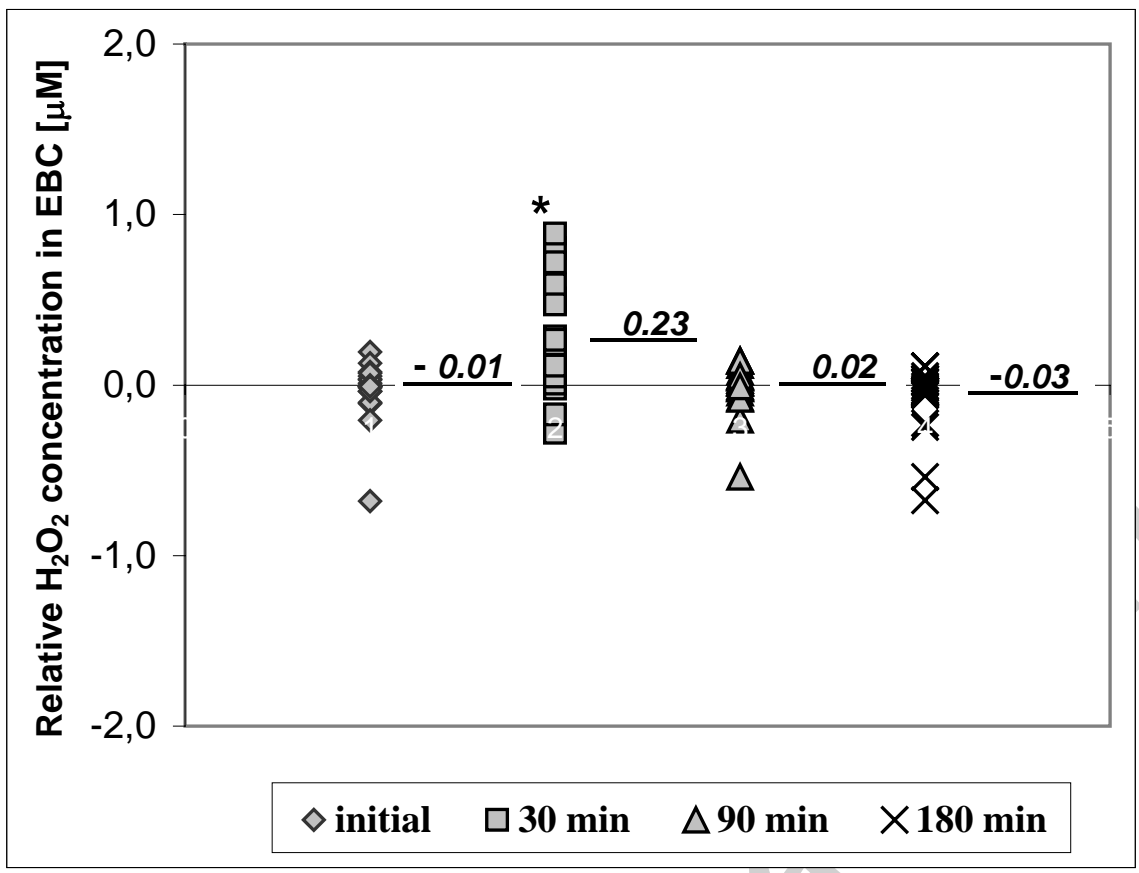

The difference between $\mathrm{H}_{2} \mathrm{O}_{2}$ concentration in exhaled breath condensate (EBC) before - initial, $30 \mathrm{~min}, 90 \mathrm{~min}$ and $180 \mathrm{~min}$ after inhalation of $3 \mathrm{ml}$ nebulized $\mathrm{N}$-acetylcysteine $(300 \mathrm{mg})$ or placebo in individual COPD patients. Relative $\mathrm{H}_{2} \mathrm{O}_{2}$ concentration is a difference between individual levels after nebulized NAC and PL. Underlined are median of $\mathrm{H}_{2} \mathrm{O}_{2}$ increase after nebulized NAC with subtracted placebo values at respective time points; $* p=0.002$ vs initial. 
Figure 2. Relative concentrations of $\mathrm{NO}_{2}{ }^{-}$and $\mathrm{NO}_{3}{ }^{-}$in exhaled breath condensate of COPD patients after inhalation of $\mathrm{N}$-acetylcysteine
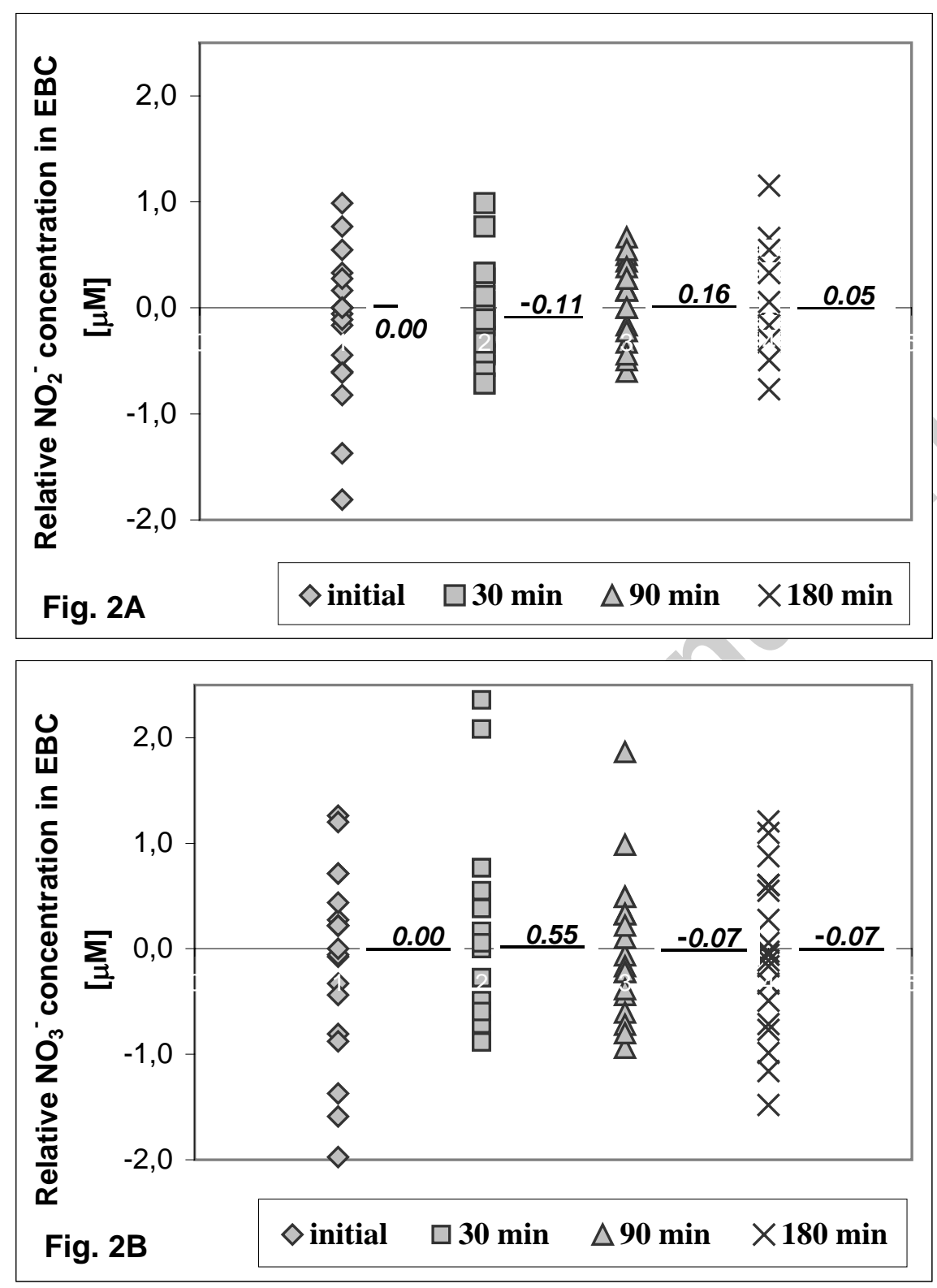

The difference between nitrite (Fig. 2A) and nitrate (Fig. 2B) concentration in exhaled breath condensate (EBC) of COPD patients before (initial), $30 \mathrm{~min}, 90 \mathrm{~min}$ and $180 \mathrm{~min}$ after inhalation of $3 \mathrm{ml}$ nebulized $\mathrm{N}$-acetylcysteine or placebo. Relative nitrite $\left(\mathrm{NO}_{2}{ }^{-}\right)$and nitrate $\left(\mathrm{NO}_{3}{ }^{-}\right)$ concentration was calculated by subtracting individual levels after nebulized PL form NAC levels. No significant differences were found in the time patterns. 
Figure 3. Relative concentrations of thiols in exhaled breath condensate of COPD patients after inhalation of $\mathrm{N}$-acetylcysteine

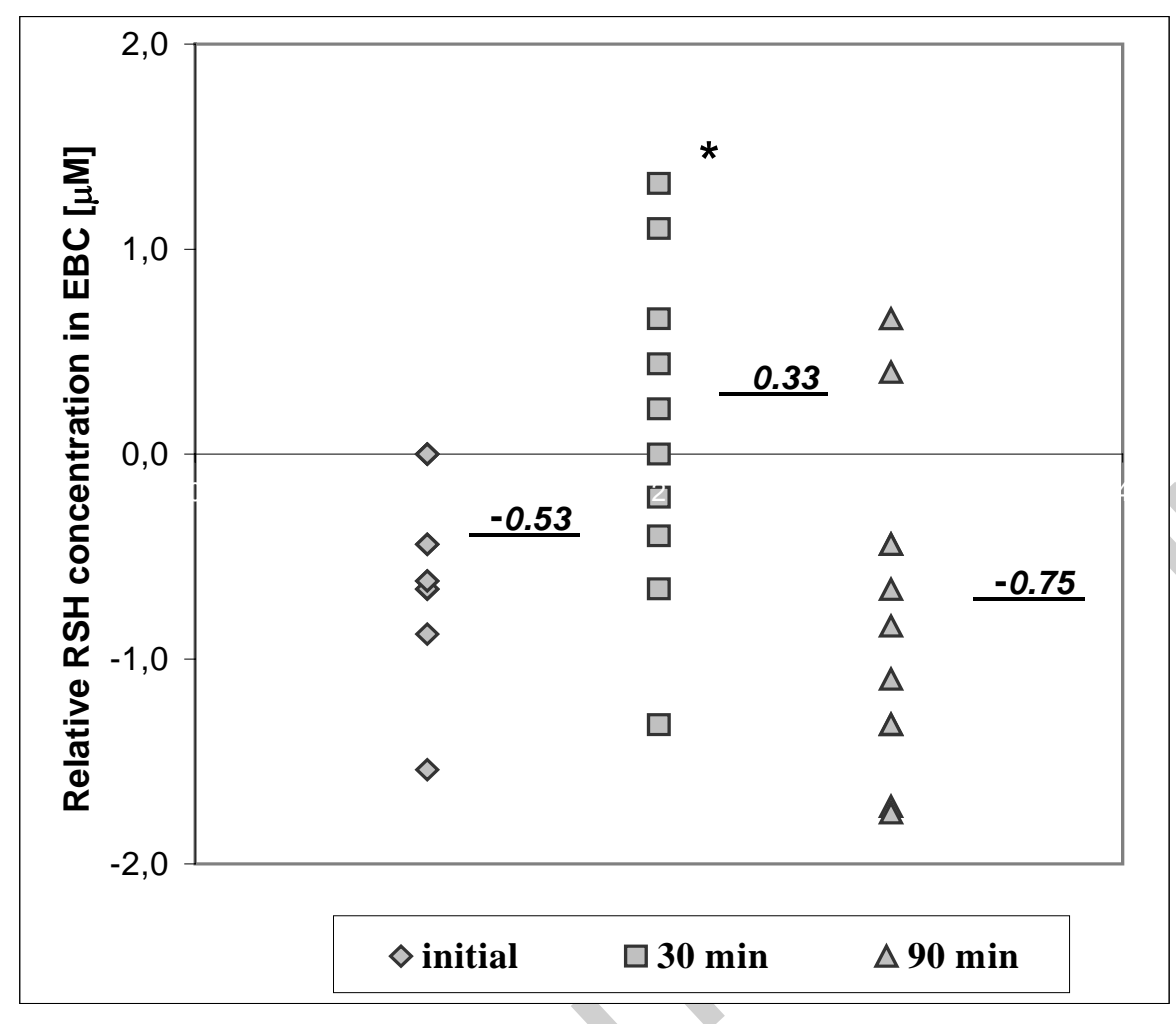

The difference between thiol (RSH) concentration in exhaled breath condensate (EBC) of COPD patients before - initial, $30 \mathrm{~min}$ and $180 \mathrm{~min}$. after $3 \mathrm{ml}$ nebulized $\mathrm{N}$-acetylcysteine and placebo. Relative RSH concentration is a difference between individual levels after nebulized NAC and PL. Underlined are median of thiol concentration increase after NAC with subtracted placebo values at respective time points. ${ }^{*} p=0.009$ vs. initial

39. 